\title{
Recent patents in RNA interference
}

\begin{tabular}{|c|c|c|c|c|c|}
\hline Patent \# & Subject & Assignee & Inventor(s) & $\begin{array}{l}\text { Priority } \\
\text { application } \\
\text { date }\end{array}$ & $\begin{array}{l}\text { Publication } \\
\text { date }\end{array}$ \\
\hline WO 2002101070 & $\begin{array}{l}\text { A method for identifying a compound that modulates } \\
\text { T-lymphocyte activation comprising contacting the compound } \\
\text { with an alpha integrin- } 2 \text { polypeptide; useful for diagnosing } \\
\text { and treating, for example, autoimmune diseases, infectious } \\
\text { diseases, or cancer through gene therapy. }\end{array}$ & $\begin{array}{l}\text { Rigel } \\
\text { Pharmaceuticals } \\
\text { (S. San Francisco, CA) }\end{array}$ & $\begin{array}{l}\text { Chu P, } \\
\text { Li C, } \\
\text { Liao XC, } \\
\text { Pardo J }\end{array}$ & $6 / 7 / 2001$ & 12/19/2002 \\
\hline WO 200299386 & $\begin{array}{l}\text { A detection device comprising an array of addressable } \\
\text { thermistors, each closely associated with either a first } \\
\text { member of a specific binding pair or to a binding or } \\
\text { reaction partner to an analyte; provides a real-time, digital } \\
\text { profile of the binding or reaction between the analyte and } \\
\text { its binding or reaction partner, and is useful for } \\
\text { multiparallel thermal analysis of samples, particularly } \\
\text { of nucleic acids. }\end{array}$ & $\begin{array}{l}\text { Proligo } \\
\text { (Boulder, CO) }\end{array}$ & $\begin{array}{l}\text { Roach JS, } \\
\text { Wolter A }\end{array}$ & $6 / 7 / 2001$ & 12/12/2002 \\
\hline WO 200297114 & $\begin{array}{l}\text { A short interfering RNA (siRNA) nucleic acid molecule or an } \\
\text { enzymatic nucleic acid molecule that modulates expression } \\
\text { of a nucleic acid molecule encoding HER2, K-Ras, H-Ras, } \\
\text { N-Ras, human immunodeficiency virus (HIV), or a } \\
\text { component of HIV. }\end{array}$ & $\begin{array}{l}\text { Ribozyme } \\
\text { Pharmaceuticals } \\
\text { (Boulder, CO) }\end{array}$ & McSwiggen J & $9 / 10 / 2001$ & $12 / 5 / 2002$ \\
\hline WO 200296927 & $\begin{array}{l}\text { Novel ribozymes that modulate the expression of genes } \\
\text { encoding vascular endothelial growth factor and/or VEGF } \\
\text { receptor; useful for inhibiting tumor angiogenesis in cells } \\
\text { and for treating cancer. }\end{array}$ & $\begin{array}{l}\text { Chiron } \\
\text { (Emeryville, CA); } \\
\text { Ribozyme } \\
\text { Pharmaceuticals } \\
\text { (Boulder, CO) }\end{array}$ & $\begin{array}{l}\text { Escobedo J, } \\
\text { Gordon G, } \\
\text { McSwiggen J, } \\
\text { Pavco P, } \\
\text { Sandberg J, } \\
\text { Stinchcomb D }\end{array}$ & $5 / 3 / 2002$ & $12 / 5 / 2002$ \\
\hline WO 200295071 & $\begin{array}{l}\text { A method for determining whether a product of a gene } \\
\text { is involved in preventing a replication error in a cell; } \\
\text { comprises providing the cell with a specific inhibitor for the } \\
\text { product and determining the level of functional expression } \\
\text { of a marker gene in the cell, where the level of expression } \\
\text { of the marker gene is dependent on the occurrence of the } \\
\text { replication error. The identified genes are useful for } \\
\text { developing diagnostic tools, or as targets for drug } \\
\text { development. }\end{array}$ & $\begin{array}{l}\text { Royal Netherlands } \\
\text { Academy of Arts } \\
\text { and Sciences } \\
\text { (Amsterdam); } \\
\text { Tijsterman M }\end{array}$ & Plasterk RHA & $5 / 22 / 2001$ & $11 / 28 / 2002$ \\
\hline WO 200292015 & $\begin{array}{l}\text { Compositions and methods relating to novel interactions } \\
\text { of the extracellular domain of LRP5, HBM (a variant } \\
\text { of LRP5), and/or LRP6 with Dkk, including Dkk-1 for } \\
\text { modulating lipid levels and/or bone mass; useful in } \\
\text { the treatment and diagnosis of abnormal lipid levels } \\
\text { and bone mass disorders, such as osteoporosis. }\end{array}$ & $\begin{array}{l}\text { Genome } \\
\text { Therapeutics } \\
\text { (Waltham, MA); } \\
\text { Wyeth } \\
\text { (Madison, NJ) }\end{array}$ & $\begin{array}{l}\text { Allen K, } \\
\text { Anisowicz A, } \\
\text { Bhat BM, } \\
\text { Damagnez V, } \\
\text { Robinson JA, } \\
\text { Yaworsky PJ }\end{array}$ & $3 / 4 / 2002$ & $11 / 21 / 2002$ \\
\hline WO 200288665 & $\begin{array}{l}\text { A method to evaluate the specificity of drugs intended } \\
\text { to interact with the same molecular target, to identify a } \\
\text { molecular target whose function may be modulated to } \\
\text { produce a desired biological effect, to refine the } \\
\text { determination of drug specificity for a protein molecular } \\
\text { target, and to determine differences in drug response } \\
\text { of different cell systems. }\end{array}$ & $\begin{array}{l}\text { Jarvis TC; } \\
\text { Thompson JD; } \\
\text { Impact Biosciences } \\
\text { (Boulder, CO) }\end{array}$ & $\begin{array}{l}\text { Jarvis TC, } \\
\text { Thompson JD }\end{array}$ & $5 / 1 / 2001$ & 11/7/2002 \\
\hline WO 200283862 & $\begin{array}{l}\text { A method for identifying a gene having a mutation } \\
\text { causing nonsense-mediated premature protein termination; } \\
\text { useful for identifying genes responsible for genetic disorders. }\end{array}$ & $\begin{array}{l}\text { Johns Hopkins } \\
\text { University School } \\
\text { of Medicine } \\
\text { (Baltimore, MD) }\end{array}$ & $\begin{array}{l}\text { Dietz HC, } \\
\text { Mendell J, } \\
\text { Noensie E }\end{array}$ & $4 / 13 / 2001$ & $10 / 24 / 2002$ \\
\hline WO 200281641 & $\begin{array}{l}\text { A gene (SCC-112) that is a modulator of tumor growth and } \\
\text { metastasis in certain cancer types; useful for diagnostic and } \\
\text { therapeutic applications in detecting and treating cancers } \\
\text { that involve expression of SCC-112, such as breast and } \\
\text { kidney cancers. }\end{array}$ & $\begin{array}{l}\text { Georgetown } \\
\text { University } \\
\text { (Washington, DC) }\end{array}$ & $\begin{array}{l}\text { Ahmad I, } \\
\text { Kasid UN, } \\
\text { Kumar D }\end{array}$ & $4 / 6 / 2001$ & 10/17/2002 \\
\hline
\end{tabular}

Source: Derwent Information, Alexandria, VA. The status of each application is slightly different from country to country. For further details, contact Derwent Information, 1725 Duke Street, Suite 250, Alexandria, Va 22314. Tel: 1 (800) DERWENT (info@ derwent.com). 